УДК 323(497.1)"1966"(093.2)

32:929 Бакарић В.(093.2)

342.24:329.15(497.5)"1966/1969"(093.2)

Dr Dino MUJADŽEVIĆ

\title{
STAVOVI VLADIMIRA BAKARIĆA O "CENTRALISTIČKOJ" OPOZICIJI (1966-1969)
}

\begin{abstract}
APSTRAKT: Autor raspravlja o odnosu prvaka SKH i jednog od najutjecajnijih jugoslavenskih komunista Vladimira Bakarića prema grupi koju je nazivao "centralistima" tj. prema opoziji samoupravnim reformama koje je zagovarao u razdoblju 1966-1969. Bakarić je smatrao da je riječ o idejno jedinstvenoj skupini, približno identičnoj s pristašama Aleksandra Rankovića, koja uglavnom djeluje u beogradskim bankama, reeksportnim poduzećima i medijima te raspolaže jakim utjecajem na javnost u SR Srbiji. Glavne točke prijepora između Bakarića i njegovih pristaša $i$ "centralista" bile su privredna reforma, bankarski sektor, financiranje velikih infrastrukturnih projekata te Fond za nerazvijene.
\end{abstract}

Ključne riječi: Vladimir Barakić, stavovi, "centaralisti", KPJ, Aleksandar Ranković

\section{Uvod}

Sukobi i prijepori u jugoslavenskom partijskom vrhu i društvu oko pitanja odnosa jugoslavenskog saveznog središta i republika, odnosno pitanje decentralizacije i prava republika, u razdoblju nakon Brijunskog plenuma 1966. koje je svojom djelatnošću obilježio šef SKH Vladmir Bakarić - to je po svim pokazateljima zapravo i vrhunac njegovog političkog utjecaja - nisu do sada bili predmetom posebnog povijesnog istraživanja, a memoarska literatura također nije obilna. Autori koji su pisali posebne studije o samom Brijunskom plenumu, tj. njegovom odjeku u javnosti, Milan Piljak i Katarina Spehnjak, tek su se uzgred doticali razdoblja koje je uslijedilo nakon ove prijelomne sjednice. ${ }^{1}$ Autori koji su se bavili studentskim nemirima u Jugoslaviji i

1 Милан Пиљак: „Брионски пленум 1966. године”, Токови историје 1/2010, str. 73-95; Katarina Spehnjak: „'Brionski plenum' - odjeci IV. sjednice CK SKJ iz srpnja 
međunarodnim položajem Jugoslavije, te stanjem u JNA godine 1968, Hrvoje Klasić i Mile Bjelajac, u značajnoj se mjeri u svojim radovima dotiču općih političkih odnosa i unutrašnje dinamike u tadašnjem jugoslavenskom partijskom vrhu, no nisu ih izučavali detaljnije. ${ }^{2}$ Srpska memoaristika koja obrađuje ovo razdoblja pretežito se bavi zbivanjima uoči i tijekom Brijunskog plenuma 1966, dok hrvatska težište stavlja na zbivanja 1970-1971. poznata kao "Hrvatsko proljeće" ili "Maspok". ${ }^{3}$

Temelj ovog rada predstavljaju autorova istraživanja u Osobnom fondu Vladimir Bakarić (OFVB) u Hrvatskom državnom arhivu (HDA). OFVB je nastao unutar administracije CK SKH prikupljanjem Bakarićevih istupa i materijala koji su mu dolazili i u sklopu njega se nalaze i gotovo svi njegovi istupi (inače ne pretjerano česti) na različitim jugoslavenskim i hrvatskim, državnim i partijskim tijelima u ovom razdoblju. OFVB sadrži dijelom građu državnih i partijskih organa koja se nalazi u drugim fondovima, osobito u fondovima CK SKH (HDA) i CK SKJ (Arhiv Jugoslavije), ali također transkripte Bakarićevih privatnih sastanaka i, u manjoj mjeri, privatnu korespond enciju i bilješke. Ovaj fond donedavno nije bio temeljito istražen te mu znanost, posebno srpska i hrvatska historiografija, tek trebaju posvetiti veću pažnju. Za drugu polovicu 60-ih, period kojim se bavimo u ovom radu, građa u OFVB je osobito obilna i predstavlja fond koji daje najbolji pregled za istraživanje Bakarićeve političke djelatnosti u ovom razdoblju te jednu od nadragocjenijih zbirki izvora za jugoslavensku povijest druge polovice 60 -ih uopće. ${ }^{4}$

1966. godine u hrvatskoj političkoj javnosti", Časopis za suvremenu povijest, br. 3, 1999, str. 463-489. Piljak donosi prikaz zbivanja iz perspektive srpske političke i historiografske tradicije, Spehnjak pak iz hrvatske. Ocjene Brijunskog plenuma i pada A. Rankovića iz različitih perspektiva v. također kod: Jovan P. Popović, Četvrta sednica CK SKJ. - Brionski plenum, Beograd, 1999, str. 47-50; Branko Petranović, Istorija Jugoslavije 1918-1988, sv. 2, Beograd, str. 571-572; Povijest Saveza komunista Jugoslavije, Beograd, 1985, str. 431-432; Dušan Bilandžić, Hrvatska moderna povijest, Zagreb, 1999, str. 489-503; Zdenko Radelić, Hrvatska u Jugoslaviji, Zagreb, 2006. str. 363-366; Ivo Goldstein, Hrvatska 1918-2008, Zagreb, 2008, str. 507-508.

2 Hrvoje Klasić, Jugoslavija i svijet 1968, Zagreb, 2012; Миле Бјелајац, „ЈНА на искушењима 60-их година прошлог века", 1968 - 40 година после, Београд, 2008.

3 Kao najznačajnije primjere srpske memoaristike v.: Dobrica Ćosić, Piščevi zapisi, 1-2, Beograd, 2000. i Aleksandar Ranković, Dnevničke zabeleške, Beograd, 2001. Hrvatsku memoaristiku zastupaju Miko Tripalo, Hrvatsko proljeće, Zagreb, 1990; Savka Dabčević-Kučar, Sedamdesetprva. Hrvatski snovi i stvarnost, sv. 1-2, Zagreb, 1997.

4 Dino Mujadžević, Bakarić. Politička biografija, Zagreb, 2011, str. 10-12. Moja monografija temelji se dobrim dijelom na OFVB i predstavlja prvo temeljito, no nipošto potpuno i konačno istraživanje ove građe. 
Fokus ovoga rada su prve godine dominacije Kardeljeve i Bakarićeve skupine u vrhu SKJ, razdoblje 1966-1969. Namjeravam dati vrlo detaljan pregled stavova hrvatskog političkog moćnika Vladimira Bakarića o političkim suparnicima nove vladajuće strukture. U ovom razdoblju Bakarićeve izjave, kako na javnim tako i na tajnim sastancima, posvećene su suzbijanju opozicije koje je djelovala u Beogradu i drugdje, pretežito u ekonomskom i medijskom sektoru ali i u saveznim i srbijanskim partijskim tijelima, protiveći se tekovinama koju je donijela prevlast njegove frakcije: političkoj decentralizaciji i smanjenju državnog intervencionizma u gospodarstvu, no ne nužno i relativnoj društvenoj i političkoj liberalizaciji koju je ona zastupala. U očima Vladimira Bakarića bili su to pristaše ili čak isti ljudi koji su bili politički marginalizirani u vrhu SKJ uoči i tijekom 1966. U brojnim transkriptima sastanaka Bakarića i njegovih najbližih suradnika sačuvanih u OFVB, koji su i glavni izvori za ovaj rad, ti se politički oponenti najčešće nazivaju "centralistima". U nekim izvorima iz druge polovice 60-ih Bakarić i njegovi suradnici često govore o "birokratizmu" i pristašama "starog sistema", misleći na približno istu skupinu oponenata najnovijim samoupravnim reformama. Važno je napomenuti da to nisu termini koje su koristili sami Bakarićevi oponenti u ovom razdoblju da bi sebe opisali te da je riječ o generaliziranju, često s vrlo malo pokrića. Sve upućuje da kritičari novog rukovodstva SKJ, baš kao i sama skupina oko Kardelja i Bakarića, nisu bili heterogena skupina, ako su uopće i bili skupina. Iz vizure Vladimira Bakarića njegovi su oponenti bili jasno definirana suparnička skupina $s$ jasnim ciljem $i$ obilježjima, no, čini se, da je stvarno stanje bilo mnogo kompleksnije. Buduća historiografska istraživanja trebala bi dati jasniju strukturu o Kardeljevim i Bakarićevim kritičarima iz ovog razdoblja, a ovaj rad, koji se ograničava na Bakarićev doživljaj konflikta, dati poticaj daljnjem istraživanju. ${ }^{5}$

\section{Vladimir Bakarić i njegova frakcija}

Vladimir Bakarić je kao osoba od najvećeg povjerenja jugoslavenskog državnog i partijskog šefa Josipa Broza Tita od jeseni 1944.

5 Neke općenite napomene o samupravnoj reformi u razdoblju 1966-1979. mogu se naći u sljedećim monografijama: Petranović, Istorija Jugoslavije, sv. 2, str. 569580; Povijest Saveza komunista, str. 432-444; Latinka Perović, Zatvaranje kruga. Ishod političkog rascepa u SKJ 1971-1972, Sarajevo, 1991; Bilandžić, Hrvatska moderna, str. 504-507, 528-537; Radelić, Hrvatska u Jugoslaviji, str. 379-381; Goldstein, Hrvatska 1918-2008, str. 534-536. 
bio na čelu hrvatskih komunista (u razdoblju 1945-1953. bio je i na čelu hrvatske vlade). Između 1953. i 1966. obnašao je dužnost sekretara Izvršnog komiteta Centralnog komiteta Saveza komunista Hrvatske (IK CK SKH) te je nakon statutarnih promjena 1966, koje su predviđale uvođenje dužnosti predsjednika i predsjedništva CK SKJ i CK republičkih i pokrajinskih partijskih ogranaka, ostao na čelu IK CK SKH kao predsjednik, zadržavši se na toj dužnosti sve do proljeća 1969. godine. Bakarićevi su istupi u razdoblju 1966-1969. bili ponajviše posvećeni gospodarskom stanju u cijeloj Jugoslaviji. Širenje njegovog ekonomsko-teorijskog i komentatorskog interesa na čitavu Jugoslaviju bilo je popraćeno ravnomjernim povećanjem njegove moći. Naime, njegov utjecaj na saveznoj razni, kao jednog od dvojice vođa vladajuće hrvatsko-slovenske "reformske" frakcije u vrhu SKJ, bio je izrazito značajan u ovom razdoblju, neposredno nakon pada Aleksandra Rankovića 1966. Napustivši godine 1969. čelno mjesto SKH, njegova su javna vidljivost i utjecaj prilično opali, premda je nastavio djelovati iz sjene sve do velikog povratka na javnu scenu $1974 .{ }^{6}$

Što je omogućilo da razdoblje 1966-1969. bude vrhunac Bakarićeva političkog djelovanja, period koji je tako značajno obilježio djelovanjem u javnosti i iza zatovorenih vrata? Uklanjanje Aleksandra Rankovića iz vrha SKJ na dramatičnom Brijunskom plenumu 1966. omogućilo je - uz potpoporu jugoslavenskog predsjednika i šefa SKJ Josipa Broza Tita - konačnu uspostavu prevlasti skupine političara na čelu s Edvardom Kardeljom i Vladimirom Bakarićem u jugoslavenskom partijskom vrhu, poznate u dijelu literature i tadašnjeg međunarodnog tiska kao "liberalna", "nedogmatska" ili „reformska" frakcija. Ovi nazivi se trebaju, naravno, uzimati s oprezom budući da je riječ o nazivima koji su koristile osobe koje nisu bile uključene u zbivanja u vrhu SKJ i koji sakrivaju pravu narav samoupravne ideologije koju su zastupali Kardelj i Bakarić. Primjerice pojedini strani novinari već 1964. nazivaju Vladimira Bakarića liderom "liberalne" frakcije unatoč tome što niti u jednom trenutku - u ovom razdoblju, kao ni ranije ni kasnije - Bakarić nije bitnije odstupio od jugoslavenskog autoritarnog jednostranačkog uređenja i kulta ličnosti Josipa Broza Tita. ${ }^{7}$

Za Bakarićevu političku djelatnost v.: Mujadžević, Bakarić.

O Bakariću kao predvodniku "liberalne struje" v. ove strane novinske tekstove: „Jugoslawien nach dem achten Parteikongreß", Neue Zuercher Zeitung, 22. XII. 
Naravno, i sam koncept frakcije nalazi se pod upitnikom jer je riječ o skupini političara koji su činili vrlo labavi i često ideološki nekoherentni savez, okupljen ponekad jedino željom da se suzbije zajednički protivnik. Ponekad su se i sami Kardelj i Bakarić razilazili oko vrlo značajnih pitanja, no čini se da su pretežito djelovali kao saveznici te je, smatram, opravdano govoriti o njima i njihovim pristašama kao zasebnoj skupini, frakciji. Kardeljeva i Bakarićeva skupina je nakon 1966. nastavila s promicanjem korjenitih ustavnih reformi utemeljenih na idejama samoupravljanja i svojim djelovanjem - nekad izravno, ponekad neizravno - otvorila prostor značajnoj političkoj decentralizaciji te određenoj - no ne i korjenitoj - gospodarskoj i društvenoj liberalizaciji u cijeloj Jugoslaviji u razdoblju između 1966. i 1972. godine. Za razliku od razdoblja prije 1966, samoupravljačka anticentralistička ideologija, koju promiču Kardelj i Bakarić, sada postaje jedina norma i na njoj razvijeni novogovor potpuno dominira javnim diskursom te je oporba takvim procesima, općenito gledano, bila u defenzivi, no ne i bez utjecaja u nekim sferama javnog života. U kasnijim godinama "reformska" frakcija postaje međutim glavni nositelj pojačane autoritarne represije i društvene konzervativnosti, a provođenje njenih ideja dovodi do ekonomskog kolapsa krajem 70-ih. ${ }^{8}$

Glavno obilježje stavova Vladimira Bakarića o unutarjugoslavenskim odnosima tijekom 60 -ih bilo je usmjereno na pokušaj balansiranja između općih jugoslavenskih interesa i partikularnih hrvatskih interesa unutar samoupravne socijalističke ideologije, čijem je oblikovanju dosta pridonjeo, iako u manjoj mjeri od Edvarda Kardelja. Smatrao je da su odnosi unutar jugoslavenske zajednice vrlo kompleksni te da svaka pojedina republika ponešto dobiva i ponešto gubi u njoj. Bakarić se žestoko i iskreno protivio hrvatskom nacionalizmu te je smatrao da je jugoslavenska zajednica najbolje rješenje za hrvatski narod, no istodobno nikada nije napuštao ulogu borca za posebne interese - ponekad vrlo konkretne - svoje partijske i društvene baze, hrvatskih samoupravljača. Hrvatski samoupravljači su trebali, naglašavao je u ovom razdoblju, osigurati prvenstveno svoje klasne interese

1964; "Yugoslav Scores Party Stalinists. He Says Some 'Politicians' Hinder Decentralization", The New York Times, 22. IX. 1964.

8 O pitanju karaktera i naziva Kardeljeve i Bakarićeve frakcije v.: Dennison Rusinow, Yugoslav Experiment 1948-1974, Berkley - Los Angeles, 1978, str. 158-159; J. R. Lampe, Yugoslavia as History, 2000, str. 289-291; Sabrina P. Ramet, The three Yugoslavias. State Building and Legitimitation, 1918-2005, Washington 2006, str. 209-212, 218-219; Mujadžević, Bakarić, str. 214-257. 
kroz samoupravne reforme tj. decentralizaciju svih oblika upravljanja, ne samo na razini jugoslavenskog centralnog nego i na republičkom nivou. Očekivao je da će i samoupravljači iz redova drugih naroda doći do identičnog zaključka i surađivati na ravnopravnim osnovama unutar Jugoslavije. Radi ostvarenja tog cilja bilo je potrebno, držao je, suzbiti "stare snage" koje su, tvrdio je, željele zadržati centraliziranu saveznu državu $s$ jakim središtem u Beogradu, baš kao što je želio suzbiti istovremeno i partikularne nacionalizme. Jačanje nacionalne države tj. republike držao je pogrešnim i žestoko ga je osuđivao, no u stvarnosti reforme koje je promicao doprinosile su upravo tome. Bakarić je smatrao da će radnička klasa u temeljito decentraliziranom, samoupravnom društvu samostalno izabrati južnoslavensku suradnju i povezivanje i odbaciti nacionalizam.

Bakarićeva optimistična očekivanja o samoupravljanju su se već krajem 60-ih pokazala iluzornim, a nacionalna euforija početkom 70-ih u Hrvatskoj i neke druge devijacije - neželjena posljedica njegovih reformi - nagnale su ga da se povno okrene povećanoj autoritarnoj represiji kao obliku provođenja samoupravnih reformi. Borbu za svojevrsnu hrvatsku emancipaciju od saveznog centra, koju je upravo Bakarić vodio iza zatvorenih vrata, preuzeli su njegovi nasljednici u Hrvatskoj - Savka Dabčević-Kučar i Miko Tripalo - i dali joj nacionalo obojene tonove. Od strane najvećeg dijela nacionalno orijentirane, partijske i izvanpartijske opozicije u Hrvatskoj Bakarić je doživljavan kao izrazito jugoslavenski političar i glavni neprijatelj istinske hrvatske nacionalne emancipacije, dok je u drugim dijelovima Jugoslavije, osobito Srbiji, doživljavan vrlo često kao utjelovljenje hrvatskog partikularizma i demontiranja jake zajedničke države. Paradoks svih samoupravnih reformi, koje su nominalno težile demokratizaciji društva, bila je činjenica da su se provodile putem autoritarne kontrole jednostranačkog režima ne izgubivši tu osobinu do samoga kraja. ${ }^{9}$

\section{Otpor „centralista" Privrednoj reformi}

U intervjuu beogradskom listu Borbi u prosincu 1967. Bakarić je pokušao sažeti ciljeve nove "etape" privredne reforme započete 1965, glavne tekovine samoupravnih reformi na polju ekonomije u

9 O generalnim stavovima Vladimira Bakarića u ovom razdoblju, osobito o nacionalnom pitanju i ideji Jugoslavije v.: Bilandžić, Hrvatska moderna, str. 442, 607; Mujadžević, Bakarić, str. 242-252. 
tom desetljeću. Prema njegovom mišljenju trebalo je nastaviti s razvlašćivanjem birokracije, tj. državnoga aparata, koju je prvenstveno povezivao s "centralističkim" snagama, i onemogućiti toj skupini da raspolaže s "viškom rada". Njime bi u budućnosti trebali raspolagati isključivo proizvođači. Birokracija je dotada, tvrdio je Bakarić, bila prilično moćna pa joj se dogodilo da "gubi u klasnoj svijesti i revolucionarnosti" i ne može shvatiti "sljedeću etapu razvitka". Prema programu CK SKJ, koji je Bakarić podržao, do 1970. trebalo je ostvariti da privredi od "viška vrijednosti ... određenog za materijalnu reprodukciju" ostaje na raspolaganju $70 \%$. Ostatak od $30 \%$ trebao je ići državi i "društveno-političkim zajednicama" i moralo ga se upotrijebiti za napredak jugoslavenskoga samoupravljanja. Intervju Borbi iskoristio je da se osvrne na svoj novi interes: jugoslavensko bankarstvo, pretežito skoncentrirano u Beogradu. $U$ intervjuu je diplomatski naznačio da se ta privredna grana vrlo lako može naći "izvan neposrednog samoupravljanja", tj. pod kontrolom oporbe novoj vladajućoj strukturi u Jugoslaviji. ${ }^{10}$

Bakarić i njegovi pristaše su se sada suočavali za po sebe negativnim posljedicama liberalizacije gospodarstva, koje su sami inicirali putem privredne reforme započete 1965 . Kao što ukazuje povjesničar Fred Singleton, poduzeća - uključujući i banke - bila su više-manje slobodna od državnog nadzora na osnovu mjera usvojenih u sklopu privredne reforme. ${ }^{11}$ Sustavom se više nije upravljalo čvrstom rukom. Ako bi poduzeća došla u ruke "centralističke" ili druge oporbe, bila bi to značajna opasnost za "reformsku" frakciju jer više nije bilo puno mogućnosti da ih izravno nadzire. Bakarićeve bojazni u pogledu bankarskoga sektora ubrzo će se pokazati opravdanima.

Uz prisutnost više od tisuću delegata od 5. do 7. XII 1968. održan je VI kongres SKH. Na kongresu je Bakarić pročitao svoj poduži referat u kojem je želio prikazati rezultate privredne reforme u Jugoslaviji. Bakarić je bio oprezan pri prognoziranju budućnosti o tečaju dinara koji je, kao što je rekao nekoliko mjeseci prije, bio privremeno stabilan. Govoreći o trajnoj stabilizaciji tečaja jugoslavenske monete, Bakarić je rekao da reforma tečaja „ima mnogo više izgleda da stabilizira dinar nego što su ga imali raniji slični pokušaji, koji su završavali prostom devalvacijom dinara i nastavkom istog privrednog toka koji

10 HDA, OFVB, kut. 67, Razgovor Vladimira Bakarića sa urednicima Borbe 17. XII 1967.

11 Fred Singleton, Twentieth-Century Yugoslavia, New York, 1976, str. 154-155. 
je neminovno vodio do daljnje stvarne devalvacije". S druge strane, postojalo je mnogo otpora gospodarskoj liberalizaciji. Bakarić je istaknuo da mnogi nisu shvaćali da će privredne reforme biti bolne i dalekosežne jer "taj kurs povlači za sobom čitav niz teškoća i problema koji duboko zadiru u same temelje našeg tadašnjeg društva, da je neprovediv bez društvene reforme, odlučne, temeljite promjene $u$ nizu socijalnih odnosa u samoj zemlji". Prema Bakariću privredna je reforma dovela do "korekture cijena" tj. povećane su cijene sirovina te se time pokušalo prerađivačku industriju natjerati "na bolje privređivanje". Prerađivačka industrija je prije uz relativno visoke cijene zbog nerazvijenog tržišta mogla prihodovati vrlo velika sredstva i ostati na razini niske produktivnosti. Bakarić je tvrdio da je promjena cijena nakon 1965. u Jugoslaviji vrlo brzo popravila stanje u industriji sirovina. Reforma je s druge strane dovela do pojave rasta razlika plaća u različitim gospodarskim granama a država je bila nemoćna smanjiti ih. Velika sredstva počela su dotjecati bankama i trgovinskim (reeksportnim) poduzećima, koja su zbog toga mogla postati kreditori brojnih poduzeća i oduzimala im zaradu. Zbog stroge kontrole emisije novca u svrhu onemogućavanja inflacije zavladala je opća nelikvidnost u poduzećima. Došlo je do jačanja privatnoga sektora.

Takvi su procesi, prema Bakariću, doveli do pojave zagovornika povratka "na stari sistem", u kojem su razlike plaća bile male te je država izdašno financirala potrebe poduzeća izazivajući inflaciju. Bakarić je bio mišljenja da samoupravljanje, kojemu je težila njegova reformska frakcija, ne može jamčiti jednakost primanja jer "neka poduzeća daju više na osobne dohotke, a neka manje". Neka poduzeća "uslijed monopolskog položaja i inače pogodovanog položaja" i konjunkturnog stanja na tržištu za njihove proizvode, mogu isplaćivati visoke osobne dohotke. Poduzeća koja su isplaćivala manje plaće činila su to jer su, pritisnuta konkurencijom na svjetskom tržištu i svojim velikim kapacitetima, morala održavati niske cijene, a istovremeno su morala ulagati u razvoj kako bi se održala na međunarodnom tržištu. Smatrao je također da država društvenu nejednakost ne može liječiti izravnim oduzimanjem novca onima koji zarađuju više. Teškoće $s$ kojima se susretalo gospodarstvo trebalo je prema Bakariću pripisati neprilagođenosti tržištu. Mnoga poduzeća bila su ovisna o "starom sustavu" te je gospodarstvo ostalo zakočeno u novim uvjetima. Zbog gospodarskih teškoća "počela se gubiti vjera u napredak samoupravljanja" te su se u društvu pojavile "konzervativne 
i reakcionarne tendence", osobito među mladima koji su smatrali da im je perspektiva ugrožena. ${ }^{12}$

\section{Jačanje "centralista" i Bakarićev protuudar (1968)}

Djelovanje Kardeljeve i Bakarićeve struje na reformi federacije nakon konačne pobjede nad Rankovićem u lipnju 1966. isprva nije nailazilo na mnogo stvarnog otpora, no tijekom 1968. "centralističke" oporbene tendencije su, iz Bakarićeve vizure, ponovno ojačale. $\mathrm{Na}$ to je upućivao snažan otpor koji su pripadnici "reformske" struje doživljavali pri pokušajima ukidanja velikih infrastrukturnih projekata i reforme bankarskog sustava 1968. Ovi oporbeni elementi koje je Bakarić smatrao jedinstvenenom skupinom ("centralisti"), premda poraženi u samom vrhu SKJ, djelovali su gotovo bez ikakvih problema u medijima i gospodarstvu te su uživali veliku javnu podršku, prvenstveno u SR Srbiji, a vrh SK Srbije zastupao je stavove koji su dijelom bili bliski onome što je Bakarić obično smatrao tipičnim "centralističkim" shvaćanjima - primjerice obrana saveznih infrastrukturnih projekata. Paradoksalno, razlog ovog ponovnog jačanja bila je stanovita liberalizacija gospodarstva i društva na temelju samoupravne reforme koju su gurali Bakarić i Kardelj! Državne, partijske i privredne strukture u sklopu kojih je najčešće djelovala oporba više nije bilo lako nadzirati jer središnji državni i partijski organi službeno više nisu imali tako široke ingerencije. Obračun s njima bio je gotovo nemoguć ako bi se dosljedno pridržavali osnovnih parametara samoupravne ideologije. Stoga je Bakarić morao pribjegavati metodama zaobilaznog pritiska, prvenstveno preko medija na koje je mogao utjecati.

Bakarić je u travnju 1968. u razgovoru s Božom Novakom, direktorom novinsko-izdavačke kuće Vjesnik, rekao da se u beogradskoj javnosti pojavila „opća tendenca na povratak natrag, na centralizam". Beogradsko glasilo Ekonomska politika bilo je predvodnik te tendencije. Bakarić je opisao ovaj list kao „organ aparata i to onoga od zla oca i gore matere". Ekonomska politika je u posljednje vrijeme započela s kampanjom zagovaranja investiranja u "velike objekte", što je Bakarić ocijenio kao pisanje "direktno usmjereno protiv reforme". Zbog rasta takve opozicije Boži Novaku sugerirao je da "tu možemo

12 HDA, OFVB, kut. 68, Izlaganje dr Vladimira Bakarića na VI kongresu SK Hrvatske 5. XII 1968. god. 
otvoriti jednu diskusiju", čime je dao Novaku zeleno svjetlo da Vjesnik i VUS počnu pisati protiv tih strujanja u Beogradu. Trebalo je paziti da u tome "budemo konstruktivni u smislu izgradnje sistema" te je savjetovao da bi trebalo izbjegavati kritični stil hrvatske novinarke Nede Krmpotić. ${ }^{13}$ Tijekom protucentralističke kampanje trebalo je također precizirati da hrvatsko rukovodstvo s Bakarićem na čelu ipak zagovora "izvjesni centralizam" tj. da Jugoslavija bude stvarna federacija, a ne "konfederacija republika". Prema Bakariću trenutna situacija je bila "da o svemu odlučuju republike", što "treba ukinuti". U nekim stvarima republike bi trebale odlučivati suvereno bez federacije, a u nekim uopće ne bi trebale imati riječi. ${ }^{14}$

U sklopu neizravne medijske kampanje protiv centralističkih snaga u Srbiji zagrebačko novinstvo je često pisalo i o lošem stanju Albanaca na Kosovu. Novak je Bakariću priopćio kako je VUS planirao pisati o lošem položaju Albanaca na Kosovu na osnovu materijala koji su dobili od novinara prištinskoga lista Rilindija, no uslijedile su intervencije od strane srbijanskoga partijskoga rukovodstva da se o tome ne piše. Bakarić je sugerirao Novaku da ne objavljuju sporne tekstove, no da ne odustanu od usputnoga kritiziranja Beograda zbog stanja na Kosovu. Rekao mu je da se drži "nekakvog džentlemenskog sporazuma sa Beogradom pa o tome ne pišete direktno, ali otvorite odozdola druge stvari". Zaključio je da "možemo pisati, recimo, o toj nacionalnoj renesansi dolje", tj. na Kosovu. ${ }^{15}$

U razgovoru s predstavnicima hrvatskih medija početkom ožujka 1969. Bakarić im je obećao da će hrvatsko rukovodstvo i njegovi predstavnici u Beogradu podržati njihovo pisanje u slučaju "cenzure" i da ih se neće odreći. Bakarić se tijekom razgovora retorički upitao: "na koncu konca, tko će vas cenzurirati?" I prije je bilo pritisaka iz Sekretarijata za inostrane poslove "ali smo se ipak dogovorili šta treba njih slušati i gdje ih ne treba slušati". I u budućnosti "dogovoriti ćemo se tako o svemu drugome i tu ne bi trebalo popuštati". Sebi je pripisao zasluge za relativno slobodno djelovanje tiska u Hrvatskoj: „inicirao sam jednu politiku da budete nezavisni i prilično sam se angažirao da je sprovedete". ${ }^{16}$

13 HDA, OFVB, kut. 68, Nekorigirani tekst magnetofonskog snimka razgovora Dr Vladimira Bakarića sa Božom Novakom dana 11. IV 1968. god.

14 Isto.

15 Isto.

16 HDA, OFVB, kut. 69, Neredigirani tekst magnetofonskog snimka razgovora dr V. Bakarića sa predstavnicima štampe i RTV dana 5. III 1969 god. 
Kao što je nagovijestio u intervjuu Borbi 1967, Bakarića je sve više zanimalo pitanje jugoslavenskog bankarstva. Tijekom 1968. to je pitanje zaoštrio u svojim javnim istupima. Bakarić je sada tražio reformu jugoslavenskog bankarskog sustava jer su neke banke i izvozna trgovinska (reeksportna) poduzeća, pretežito sa sjedištem u Beogradu, putem kredita - koje su mnoga poduzeća zbog raširene nelikvidnosti morala uzimati - postali vjerovnici dobrom dijelu gospodarstva i, umjesto radnika, stvarni korisnici dohodaka koje su ostvarivala poduzeća. Time su osobito bila pogođena hrvatska turistička poduzeća koja su privređivala lavovski dio jugoslavenskih deviza, no morala su ih davati za otplatu kredita bankama i reeksportnim poduzećima. Prema Bakariću to nije bilo samo pitanje gospodarske neravnopravnosti, nego i raspodjele političke moći. Bakarić je u razgovoru s Božom Novakom u travnju 1968. upozorio da "centralistička" struja sada ima uporište u bankama i velikim reeksportnim poduzećima te bi to treblo spriječiti ("to bi morali da rasčepusamo"). Prema Bakariću beogradskim bankama i reeksportnim poduzećima sada "komanduje nekoliko dripaca tamo - ustvari udbovaca starih", očito aludirajući na Rankoviće pristaše koji su bili donedavno jaki u saveznoj UDB-i. Za njega je njihovo ponašanje bilo „čista pljačka Jugoslavije ... i to beogradska pljačka". Strukture koje su dominirale u bankama kontrolirale su sada putem svojih kredita jugoslavenske investicije tj. ukupan društveni razvoj, a to im je upravo omogućila privredna reforma započeta 1965. - za koju se, paradoksalno, izborio upravo Bakarić. Upravni odbori banaka i reeksportnih poduzeća bili su samostalni u odlučivanju o investicijama. Bakarić je smatrao da to nije bilo u skladu sa samoupravnim idealima jer privreda od čijih su kamata živjeli "na to nikakvog uticaja nema, a žive ustvari od društvenog monopola koji imaju", žalio se Bakarić. Želio je to što prije promijeniti. ${ }^{17}$

U drugoj polovici godine Bakarić je prešao u javnu ofenzivu protiv beogradskih banaka i reeksportnih poduzeća. U listopadu 1968, u govoru jednoj manjoj skupini članova SKH podsjetio je da beogradske banke sada raspolažu sredstvima koja su se nekad nalazila u saveznim fondovima. Iako je država uvela upravne odbore u bankama kako bi bankovne investicije i krediti bili pravednije raspoređeni, Bakarić je

17 HDA, OFVB, kut. 68, Nekorigirani tekst magnetofonskog snimka razgovora Dr Vladimira Bakarića sa Božom Novakom dana 11. IV 1968. god. 
javno izrazio bojazan zbog prevelikog utjecaja direktora banaka koji su sada rapolagali s izuzetnom moći. ${ }^{18}$

Uskoro je uslijedila i njihova osuda pred još većim auditorijem. Naime, u referatu na VI kongresu SKH u prosincu 1968. Bakarić je još jasnije javnosti progovorio o ulozi beogradskih banaka i izvoznih trgovinskih (reeksportnih) poduzeća u iskorištavanju hrvatskih poduzeća. Oni su davali kredite poduzećima pod uvjetima koji „oduzimaju praktički sav višak rada" te su "kolektivi često pritisnuti na golo pokrivanje troškova poslovanja i osobnih prihoda". Osobito teško su bila pogođena turistička poduzeća u Hrvatskoj, koja rade "na granici rentabilnosti zbog visokih kamata i visokih anuiteta otplate duga". Bakarić je takvo kreditiranje smatrao protivnim samoupravnom socijalizmu jer "ima u sebi mnogo kapitalističkih elemenata" i „ide putem /bankovnog/ kapitala koji traži najbolje područje za svoje oplođivanje". U konačnici takav kredit pridonosi "rješavanju niza razvojnih problema ali konzervira neke društvene odnose". ${ }^{19}$ Pitanje deviza koje su iz hrvatskih poduzeća odlazile bankama i reeksportnim poduzećima, koje je javno tijekom 1968. pokrenuo upravo Bakarić, postat će 1970-71. jedna od glavnih, emocionalno najnabijenijih, tema tijekom Hrvatskog proljeća. U očima pristaša nacionalnog buđenja bio je to moćan simbol iskorištavanja Hrvatske od strane Beograda, no tada je Bakarićeva uloga u pokretanju ovoga pitanja već bila zaboravljena!

\section{Sukobi izbijaju na vidjelo: prijepori oko bilanca federacije}

U ovom razdoblju Bakarić se javno i oštro protivio izgradnji novih velikih infrastrukturnih objekata iz saveznoga proračuna, koje su osobito zagovarali predstavnici SR Srbije. Ti su projekti iziskivali velika sredstva, što je prema Bakariću kočilo jugoslavensko gospodarstvo. Od tih projekata najčešće je spominjana hidorelektrana Đerdap, pruga Beograd-Bar i kanal Dunav-Tisa-Dunav. U razgovoru s predstavnicima RTV Zagreb Bakarić je u rujnu 1968. izjavio da bi trebalo dovršiti tek neke od tih projekata, poput hidroelektrane Đerdap, a druge stopirati. Smatrao je da tih velikih infrastrukturnih projekata ima previše u ovom

18 HDA, OFVB, kut. 25, Aktuelni problemi daljeg razvoja ekonomskog sustava, neredigovano izdanje, Razgovor druga V. Bakarića, predsednika CK SKH, s aktivom DSNO-a 25. 10. 1968. godine.

19 HDA, OFVB, kut. 68, Izlaganje dr Vladimira Bakarića na VI kongresu SK Hrvatske 5. XII 1968. god. 
trenutku. Ti projekti nisu poželjni jer "dugo ne donose ništa" i potiču isključivo građevinsku industriju, što je smatrao djelatnošću „koja ne vuče napred, nego je na klasičnoj bazi i koja nam onda niz godina preči dalji razvoj". ${ }^{20}$

Bakarić je ovaj problem u javnosti predstavljao kao opće jugoslavenski, no sve upućuje da je bio uvjeren da Hrvatska (kao i Slovenija) ima više razloga od drugih republika da se prekine s ovim projektima. Bakarić i njegovi hrvatski istomišljenici iz vladajuće frakcije u vrhu SKJ smatrali su da je Hrvatska kao razvijena republika posebno oštećena ovom praksom jer obilno mora potpomagati zarađenim novcem, koji bi joj samoj dobro došao, financiranje infrastrukturalnih projekata u manje razvijenim republikama. Prema samupravnoj ideologiji koju su zastupali, proizvođačima tj. poduzećima bi trebao ostajati na raspolaganju njihov dohodak i ne prelijevati se putem izdvajanja za državnu, u ovom slučaju saveznu kasu te, posredno, u manje razvijene republike. Bakarić je raspolagao informacijama da su hrvatska (i slovenska) poduzeća privređivala relativno najviše sredstava te su najviše gubila preraspodjelom. Primjerice, tijekom spomenutog razgovora s urednicima novinsko-izdavačke kuće Vjesnik i RTV Zagreb početkom ožujka 1969. Bakarić je okupljenima izjavio da se Hrvatska "od 1945. na ovamo" eksploatira. Ipak, Bakarić je smatrao da puko prozivanje Beograda te neprestano žaljenje ne može riješti problem, nego samo hraniti međunacionalnu i međurepubličku nesnošljivost i ojačati nacionaliste. O ovoj tematici je želio oprezno i obazrivo raspravljati, po mogućnosti iza zatvorenih vrata. ${ }^{21}$

Bez obzira na Bakarićeve želje, prijepor oko financiranja spomenutih velikih infrastrukturnih projekata iz saveznog proračuna, postavši poznat u tadašnjoj javnosti kao "debata o bilancama federacije", prodro je početkom 1968. u jugoslavensku i hrvatsku javnost. Bio je to najozbiljniji sukob vladajuće frakcije (u ovom slučaju njenih hrvatskih predstavnika) s, uvjetno rečeno, "centralistima" nakon Brijunskoga plenuma 1966. godine. Bakarić i drugi vodeći ljudi SKJ su se u tu raspravu uključili protiv svoje volje plašeći se, kao što je već rečeno, posljedica po međunacionalne i međurepubličke odnose. Ta

20 HDA, OFVB, kut. 25, neredigirani tekst magnetofonskog snimka razgovora dr Vladimira Bakarića sa predstavnicima RTV Zagreb i Vjesnika - dana 28. XI 1968. O prijeporima reformske i centralističke frakcije, odnosno predstavnika Hrvatske i Srbije, u vrhu SKJ 1968. v.: Bilandžić, Hrvatska moderna, str. 522-525.

21 HDA, OFVB, kut. 69, Neredigirani tekst magnetofonskog snimka razgovora dr V Bakarića sa predstavnicima štampe i RTV dana 5. III 1969 god. 
je rasprava prijetila da se pretvori i u javni sukob između Hrvatske i Srbije, pa je vrh SKJ pokušao sve da rasprava ostane iza zatvorenih vrata. Debata je došla u novine, no zbog pritiska partijskoga vrha o njoj nije puno raspravljano. Na sjednici Predsjedništva CK SKJ 4. travnja 1968. Bakarić je pokušao objasniti razvoj toga prijepora i svoju ulogu u njemu. Rekao je da se već tijekom 1967. pojavio veliki pritisak unutar SKJ da se o tome raspravlja te je Predsjedništvo CK SKJ načelno prihvatilo da se diskutira o bilancama federacije. I među hrvatskim komunistima bilo je puno želje da se ovo pitanje pretrese.

Na Konferenciji GK SKH Zagreba 22. ožujka 1968. Bakarić je bio, ustvrdio je, izložen "pritisku” da o tome govori, no izbjegao je. Istovremeno se i u hrvatskim poduzećima pojavio "veliki pritisak ... da se ide na javnu diskusiju". IK CK SKH je potom ipak odlučio iznijeti tu temu kao sporednu točku na sjednici Predsjedništva CK SKJ, no istodobno je zaključeno "da ne treba da insistira" na javnoj raspravi o bilancama federacije. Za taj su stav imali potporu Predsjedništva CK SKJ koje je također bilo za to da se o bilancama federacije ne raspravlja u javnosti. GK SKH za Zagreb podržao je taj stav hrvatskoga partijskoga vrha, no novine su sutradan prenijele izjavu člana toga tijela Marinka Grujića koji je "ponovio izjavu da treba ići na javnu diskusiju". Hrvatsko rukovodstvo je interveniralo i spriječilo da se ta izjava ponovi u drugom izdanju novina. No, i drugi hrvatski novinari su počeli pisati o tome, pa je čitava stvar ipak prodrla u javnost. Oglasile su se i srbijanske novine. ${ }^{22}$ Bakarić je 11 . travnja 1968. u razgovoru s Božom Novakom spomenuo kako je Predsjedništvo CK SKJ, bojeći se "velike diskusije", odlučilo "utišati štampu" i ne davati nikakve službene izjave o tom pitanju. ${ }^{23}$

U razgovoru s novinarom Marinkom Grujićem 11. travnja 1968. Bakarić je dao svoje objašnjenje osnove pitanja bilanca federacije. Riječ je bila o investicijama koje su na razini jugoslavenske federacije isplanirane još prije provođenja privredne reforme 1965 . U vrijeme početka reforme SIV je pod vodstvom Borisa Krajgera, odlučio da, usprkos reformi koja je smanjivala federalne investicije, federacija nastavi s preuzetim obvezama do 1970 . godine. U međuvremenu je u SIV-u prevladalo mišljenje da zbog ekonomske situacije nije moguće izvršiti obveze te da one guše daljnji razvoj gospodarstva. Najave

HDA, OFVB, kut. 68, 4. IV 1968, Diskusija dr. V. Bakarića na sjednici Predsjedništva SKJ.

$23 \mathrm{HDA}, \mathrm{OFVB}$, kut. 68, Nekorigirani tekst magnetofonskog snimka razgovora dr Vladimira Bakarića sa Božom Novakom dana 11. IV 1968. god. 
ukidanja investicijskih programa su, tvrdi Bakarić, izazvale buru negodovanja u Srbiji jer se "čitava politika temeljila ... u Srbiji ... na ispunjavanju tih obaveza". Riječ je bila o velikim infrastrukturnim projektima. Srbijanski partijski vrh angažirao je stručnjake koji su dokazivali da se obaveze mogu ispuniti. Prema Bakariću, obveze federacije iznosile su 500 milijardi dinara, dok su u Srbiji tvrdili da su samo 270 milijardi. U Srbiji su također tražili da, ako ne bude dovoljno sredstava, prioritet dobiju obveze na teritoriju nerazvijenih republika, protiv čega su se pobunili predstavnici razvijenih republika. Bakarić je podržavao zabranu javne rasprave o tom pitanju bojeći se da hrvatski i srpski nacionalisti to ne iskoriste za svoje ciljeve. Negirao je s druge strane da je sam spor nacionalne prirode, premda ga "hrpa nacionalista" takvim pokušava prikazati. Ako se dopusti širenje te raprave, ona "će nas u prvom redu još jače posvađati". Bakariću su predstavnici SR Bosne i Hercegovine kazali da je spor zapravo "srpsko-hrvatski" i da se njih ne tiče. Prema Bakariću, bila je to "potpuna neistina" jer se rasprava o bilancama federacije odnosila na budućnost samoupravne reforme koju je zagovarao. Smatrao je da takve tvrdnje koriste "centralistima" iz Srbije "jer oni isto tvrde da je to srpsko-hrvatski spor, jer im to treba da prikažu kao nacionalistički napad na Srbiju". ${ }^{24}$

Međutim tijekom travnja i svibnja 1968. kontroverza oko bilanca federacije nije se smirila. Bakarić je u međuvremenu odlučio čvrsto stati iza zahtjeva da se pitanje bilanca riješi, iako iza zatovrenih vrata, te se radi toga, uz najbliže suradnike Miku Tripala i Savku DabčevićKučar, osobno angažirao u Beogradu. Ipak, predstavnici drugih republika u vrhu SKJ nisu željeli sudjelovati u tome želeći ostati neutralni ili čak nastupajući otvoreno neprijateljski prema hrvatskom zahtjevu. Šestoga lipnja 1968. održan je informativni sastanak jednog dijela IK i Predsjedništva CK SKH. Miko Tripalo informirao je prisutne, među kojima se nalazio Bakarić, o sastancima na kojima je prisustvovao u Beogradu. Tripalo je ondje zastupao stavove hrvatskoga rukovodstva o "raščišćavanju" bilanca federacije na sjednici SIV-a, zajedničkoj sjednici IK i Predsjedništva CK SKJ te na zajedničkoj sjednici Predsjedništva i Izvršnog biroa Predsjedništva CK SKJ. Zaključke SIV-a o rješenju problema bilanca federacije, koje je prezentirao Tripalo, hrvatsko

24 HDA, OFVB, kut. 68, Neredigirani tekst magnetofonskog snimka razgovora dr Vladimira Bakarića i Marinka Gruića dana 11. IV 1968. god. O raspravi o bilanci federacije 1968. v.: Bilandžić, Hrvatska moderna. 
je rukovodstvo ocijenilo „apsolutno nedovoljnim" jer bi „postojeći odnosi u raspodjeli ostali ... ustvari isti", što "ni politički ni ekonomski još dugo to izdržati ne možemo". Tripalo je također rekao da je hrvatsko partijsko rukovodstvo, nakon što ni IK SKJ nije prihvatio hrvatska upozorenja, odlučilo još jednom ukazati na problem platne bilance, pa je Bakarić o tome razgovarao s Titom u Karađorđevu.

Na zajedničkoj sjednici Predsjedništva CK SKJ i Izvršnog biroa Predsjedništva CK SKJ koja je uskoro uslijedila odlučeno je da se hrvatski prigovori privremeno gurnu pod tepih pa se nije raspravljalo o bilancama federacije. Formirana je komisija čiji su članovi bili Edvard Kardelj, Mika Špiljak i Bakarić, koja je trebala koordinirati „sistemska rješenja" kako bi se ubuduće izbjegli nesporazumi takve vrste. Tripalo je bio svjestan da predstavnici drugih republika nisu rado gledali na hrvatske zahtjeve te i osnivanje spomenute komisije nije prihvaćeno "rado, iako nitko nije oponirao". Prema Tripalu, ostali su željeli preglasati hrvatske predstavnike i optužiti vrh SKH "za izazivanje političke krize u zemlji i pokušaj da kao - iako smo samo jedna republika - nametnemo svoje mišljenje drugima". Na istom se sastanku Savka Dabčević-Kučar osvrnula na recentne napise u beogradskim listovima NIN i Večernje novosti, u kojima se tvrdilo da raspodjela prihoda među federalnim jedinicama nije bitna te da je Hrvatska zastupajući "poseban interes" isključivo koncentrirana na pitanju raspodjele. Njihove je članke nazvala "kampanjom dezinformacija".

Bakarić je govoreći nakon Dabčević-Kučar rekao da su "Srbi" (tj. predstavnici CK SK Srbije) tražili od Tita da se o hrvatskim stavovima raspravlja bilo na plenumu CK SKJ, bilo na sjednici Predsjedništva CK SKJ. Prema Bakariću Tito je pristao na sjednicu Predsjedništva, ali je predstavnicima partijskoga vrha Srbije rekao kako je „bar jedan dio toga usmjeren na njega a ne na nas", misleći očito da je otpor hrvatskim stavovima u Srbiji također i prikrivena kritika samog Tita, koji je inače čvrsto podupirao hrvatsko partijsko vodstvo. Bakarić je također opisao i negativne reakcije predstavnika drugih republika na hrvatsku želju da se raspravi pitanje bilanca federacije, koje su izražene na zajedničkoj sjednici Predsjedništva i IK CK SKJ na Brijunima koja je održana početkom lipnja 1968. godine. Predstavnici drugih republika su Bakariću kazali „da se mi svađamo sa Srbima i da od toga strada cijela Jugoslavija". Hrvatsko rukovodstvo bi trebalo imati više razumjevanja i ne bi smjelo nastupati tako oštro protiv predstavnika Srbije budući da je "srpsko rukovodstvo u teškoj situaciji jer je moralo 
da progura Rankovića, moralo je da proguta svinjarije na Kosovu, treba da proguta sporove sa Vojvodinom, treba da proguta makedonsku crkvu", savjetovali su Bakariću. On je odbacio njihove optužbe na svoj račun te je predložio "da se sastanemo sa Srbima i s bilo kim tko hoće, da nam je to sasvim svejedno". Predsjednik Josip Broz Tito je pristao i sazvao je sastanak za slijedeći dan, no zbog studetskih prosvjeda sastanak nije održan. Bez obzira na otpore i privremeni neuspjeh, Bakarić je bio zadovoljan s postignutim u "ovoj bitki" koja se započela s debatom oko bilanca federacije. Hrvatsko rukovodstvo postiglo je "sve što se u ovom momentu moglo postići". Uspjelo se upozoriti da obaveze federacije "nemaju čvrste izvore svojih sredstava" te da je "nemoguće da se financiranje tih stvari rješava dalje onako 'lako ćemo". Primijetio je da su se dosada ti problemi rješavali prikrivanjem pravoga stanja bilanci. Ipak, bio je protiv da ovi sukobi dospiju "kod širih partijskih foruma" jer se takvim pritiskom ništa ne može postići. Bio je svjestan da se reforma federacije "ne može nametnuti". Hrvatsko rukovodstvo je trebalo voditi računa da je Jugoslavija "mnogonacionalna zemlja" $\mathrm{s}$ "mnogo kompliciranim stvarima”. Naglasio je da nudi razgovore i pokazuje dobru volju. Odbio je na sastanku imenovati „protivnike reforme" jer su oni istomišljenici i saveznici u nekim stvarima, a u nekim protivnici hrvatskoga rukovodstva, pa bi ih otvorena konfrontacija zauvijek otuđila. ${ }^{25}$

\section{Epilog}

Bakarić, Savka Dabčević-Kučar i Miko Tripalo sastali su se naposljetku 29. lipnja 1968. u Beogradu s najvišim predstavnicima CK Srbije Petrom Stambolićem, Stevanom Doronjskim i drugima. Bakarić je svoje izlaganje na tom sastanku započeo s tvrdnjom da ne postoji "duboki spor između nas" kao što je rašireno mišljenje, nego da je riječ o "gradaciji" u stavovima hrvatskoga i srbijanskoga rukovodstva. Porekao je da hrvatsko rukovodstvo želi optužiti CK SK Srbije za "centralizam". Najveći dio svoga izlaganja posvetio je razlikama u stavovima oko saveznih organa te je pokušao prikazati hrvatsku stranu. Naglasio je da je hrvatsko rukovodstvo zahtijevalo neke promje-

25 HDA, OFVB, kut. 25, Stenografski zapisnik sa sastanka jednog dijela Predsjedništva i Izvršnog komiteta CK SK Hrvatske, održanog 6. lipnja 1968. g., str. 2. O sastanku vrha SKJ početkom lipnja 1968. v.: Ivo Banac, Raspad Jugoslavije, Zagreb, 2001, str. 30. 
ne u Saveznom sekretarijatu za vanjske poslove jer Hrvatska ima najveću emigraciju, no "baratanje s tom emigracijom" od strane jugoslavenske diplomacije je "kriminalno". Hrvatsko rukovodstvo je tražilo od Saveznog sekretarijata za vanjske poslove da „politički rad sa novijom emigracijom uzmemo $\mathrm{mi}$, tj. da uvedemo socijalne atašee $\mathrm{u}$ konzulatima koji bi se bavili tim poslom", što je prihvaćeno. Bakarić je napomenuo da hrvatsko rukovodstvo ima i probleme sa saveznim vojnim vrhom u kojem su se nalazili generali koji su bili u sukobu sa hrvatskim komunističkim vrhom. Zalagao se i za veću ulogu Vijeća naroda u Saveznoj skupštini "zato što uloga republika raste i što elementi sporazuma među republikama rastu". ${ }^{26}$

Bez obzira na opće smirenje tenzija koje su dominirale 1968, Bakarić je i kasnije nastavljao povremeno kritizirati "centralističke" tendencije, a čak je načeo neke nove teme. Snaga Bakarićeve pozicije u vrhu SKJ ogledala se i u tome što je pred predsjednikom republike i šefom SKJ Josipom Brozom Titom govorio bez rukavica o frakcijskim borbama okrivljujući čitava republička rukovodstva za nepodopštine i odstupanja od službene partijske linije. Tijekom razgovora hrvatskoga rukovodstva s Josipom Brozom Titom u Zagrebu 2. siječnja 1969. Bakarić se osvrnuo na probleme u upravljanju saveznim sredstvima. Izjavio je da je Fond za nerazvijene "došao u krizu pred godinu dana" te da su sada "oko njega ... zakulisne jako velike borbe". Prema Bakariću, Fond za nerazvijene, čiji je nastanak upravo Bakarić branio prije nekoliko godina, općenito je bio u krizi. Djelovao je "potpuno destimulativno na razvijanje bilo čega novoga" te štoviše "podržava jedan birokratizam na nekoliko centara u Jugoslaviji". Jedan od takvih centara "birokratizama" bilo je bosansko-hercegovačko rukovodstvo čiji članovi „kradu pare svojoj vlastitoj industriji" i upućuju ga u Fond za nerazvijene, odakle im se vraća. Prema Bakariću to su činili da bi bosansko-hercegovačka "vlada mogla raspolagati parama, a ne da bi razvijala industriju". Obziri prema nerazvijenim jugoslavenskim republikama kočili su, prema Bakariću, gospodarstvo. Spomenuo je da su ulaganja u profitabilno stočarstvo onemogućili zahtjevi nerazvijenih koji su i dalje tražili ulaganje u tvornice, rafinerije i željezare. Nadalje, proizvodnja čelika u jugoslavenskim željezarama bila je opterećena činjenicom što su morale kupovati željezo iz jugoslavenskih rudnika - iz nerazvijenih republika - koje je bilo i "tri puta skuplje" od željeza

26 HDA, OFVB, kut. 25, 29. VI. 1968, Razgovor u CK Srbije (tj. s Petrom Stambolićem, Stevanom Doronjskim i dr. uz prisustvo Savke Dapčević-Kučar i Mike Tripala). 
iz Brazila ili istočne Afrike. Primijetio je da se unutar vrha SKJ lako složiti o "sistemskim pitanjima", no "čim počnu u ovo dirati, onda se više nećemo složiti". ${ }^{27}$

I u javnim nastupima je Bakarić, koji je početkom 1969. odlučio otići iz prvog plana, nastavio kritizirati opoziciju samoupravnim reformama. Govoreći na Plenumu CK SKH 21. veljače 1969. Bakarić se osvrnuo na fenomen „općeg straha od tržišta" u Jugoslaviji koji je usporavao privrednu reformu i jačao opoziciju unutar SKJ. Bakarić je bio mišljenja da u Jugoslaviji nema pravoga tržišta - čak ni "slobodnog socijalističkog tržišta" - te da strahovi o ukidanju prava radnicima i otpuštanju nemaju osnova. Prema Bakariću istinski su strahovali zapravo oni koji žele "nametnuti društvu zastarjeli sistem rada, neki zastarjeli monopol i slične stvari". ${ }^{28}$

Vladimir Bakarić je kormilo SKH početkom 1969. prepustio svojoj dotadašnjoj najbližoj suradnici Savki Dabčević-Kučar te je prešao na rad u Izvršni biro Predsjedništva SKJ u Beograd. Dabčević-Kučar i njeni suradnici nastavili su voditi SKH prema anticentralističkim načelima koje je inaugurirao Bakarić u prethodnom razdoblju, no postepeno su napustili Bakarićevu opreznost i balansiranost u traženju emancipacije Hrvatske - prvenstveno na gospodarskom planu - unutar samoupravnog poretka SFRJ. Tijekom 1970. novo hrvatsko rukovodstvo iniciralo je masovni javni pokret (Hrvatsko proljeće, Maspok) koji je podržavao njihove zahtjeve. Ova je atmosfera ohrabrila nacionalističku opozciju unutar i izvan SKH koja je počela u Hrvatskoj nastupati u javnosti. Vladmir Bakarić, sada bez mogućnosti da izravno dirigira politiku SKH, sve do proljeća 1971. podržavao je novi politički kurs u Hrvatskoj, protiv kojega tada nije istupao ni sam predsjednik Josip Broz Tito. U ovom razdoblju Bakarić je kao mentor i saveznik novog hrvatskog partijskog rukovodstva nastavio doživljavati napade iz krugova savezne diplomacije, od skupine koju je u prethodnom razdoblju nazivao "centralistima". Hrvatsko rukovodstvo je tijekom 1970. tvrdilo da ima saznanja da se u emigrantskim krugovima i jugoslavenskoj diplomaciji šire vijesti o navodnim dodirima vrha SKH s hrvatskom ekstremnom nacionalističkom emigrantskom skupinom Branimira Jelića te da iza tih priča stoje centralistički krugovi u saveznoj administraciji. Naime, vrh SKH je bio obaviješten da se u nekim

27 HDA, OFVB, kut. 33, Magnetofonski snimak sastanka održanog dana 2. I 1969. god.

28 HDA, OFVB, kut. 69, Diskusija dr. V. Bakarića na III sjednici CK SKH 21. II 1969. god. 
dokumentima saveznih organa prenose obavještajni podaci o tome da Branimir Jelić tvrdi kako posreduje između hrvatskih komunista i SSSR-a radi stvaranja neovisne Hrvatske pod sovjetskim patronatom. Jelić je navodno tvrdio da je između ostalih stupio u kontakt s Bakarićem, Jakovom Blaževićem i još tri člana CK SKH. Kolale su informacije da neki dužnosnici Matice hrvatske, SSRNH i grada Zagreba kontaktiraju s "proustaškom" emigracijom. ${ }^{29}$

Na Bakarićevu inicijativu predsjednik Izvršnog vijeća SRH Dragutin Haramija je u pismu SIV-u od 2. prosinca 1970. tražio istragu o tim informacijama, koje su objašnjavali „zavjerom protiv hrvatskog rukovodstva". Oformljeno je partijsko povjerenstvo na čelu sa Stanetom Dolancom koje je trebalo ispitati slučaj. O tom se slučaju raspravljalo na sjednici Predsjedništva CK SKJ 23. ožujka 1971, no bez Titova prisustva. Stane Dolanc je izvijestio da je njegova komisija zaključila da je doista postojala organizirana kampanja s ciljem kompromitiranja vrha SKH izmišljenim vezama s emigracijom, no komisija je zaključila da je izvor kampanje u inozemstvu. Bakarić se na sastanku nije složio s ovim posljednjim zaključkom komisije. Rekao je da je upravo on pokrenuo to pitanje te da se za njega ne bi zanimao da kampanja protiv hrvatskoga rukovodstva nije imala izvor u Jugoslaviji. Prema sjećanjima Savke Dabčević-Kučar, Bakarić je na sastanku jugoslavenski izvor te kampanje nazvao "političkim podzemljem". Publicist Slavoljub Đukić tvrdi da je Bakarić na sastanku krugove koji su organizirali kampanju nazvao "beogradskom čaršijom", no da je poslije uspio postići da se izbriše ta formulacija iz zapisnika. Savka Dabčević-Kučar i Miko Tripalo podržali su Bakarićeve stavove. Tripalo je čak ukazao da su čitavu kampanju organizirali jugoslavenski obavještajni krugovi koji su imali svoje ljude oko Jelića. Predstavnici Srbije su, s druge strane, pokušavali minorizirati slučaj i tvrdili da je riječ o grešci. Sastanak je završio zaključkom da je doista postojala organizirana kampanja protiv hrvatskoga rukovodstva, no ništa nije rečeno o njenim organizatorima. ${ }^{30}$

Savka Dabčević-Kučar je na ovom sastanku Predsjedništva CK SKJ spominjala i kampanju protiv hrvatskoga komunističkoga vodstva koju vode beogradski listovi Jež, Ekonomska politika i Večernje no-

29 O ovom slučaju v.: Radelić, Hrvatska u Jugoslaviji, str. 445-446; Bilandžić, Hrvatska moderna, str. 587-588.

30 Dabčević-Kučar, '71, str. 504-513; Slavoljub Đukić, Slom srpskih liberala. Tehnologija političkih obračuna Josipa Broza, Beograd, 1990, str. 41-47. 
vosti. ${ }^{31}$ Primjerice, beogradski satirički list Jež ismijavao je hrvatsko rukovodstvo i njihove zahtjeve za jačanje ovlasti republika u odnosu na federaciju. Bakarić je tako 26. veljače 1971. u tom listu bio meta ismijavanja novinara Brane Crnčevića. Komentirajući taj članak novinar Drago Tović je u zagrebačkom VUS-u 10. ožujka 1971. primjetio da se Jež u posljednje vrijeme ruga "samo s onim što ima veze s ravnopravnošću, osobito emancipacijom naroda", a "posebno je bilo vulgarno ono obraćanje dru Vladimiru Bakariću". ${ }^{32}$

Uplašen rastom nacionalizma kod dijela pristaša novog hrvatskog rukovodstva, baš kao i negativnim reakcijama na zbivanja u Hrvatskoj koje su dolazile iz drugih jugoslavenskih republika, Bakarić se naposljetku u proljeće 1971. distancirao od Savke Dabčević-Kučar i njenih najbližih suradnika te je uz podršku Josipa Broza Tita počeo okupljati nezdovoljnike njihovom politikom. Pritisak Josipa Broza Tita i jugoslavenskog partijskog vrha omogućio je Bakariću da krajem 1971. osigura smjenu Savke Dabčević-Kučar i njenog kruga te da ponovno, ovoga puta neizravno i zakulisno, stekne kontrolu nad SKH i zadrži je do svoje smrti. Smjena hrvatskog rukovodstva i eskalacija represije nad nacionalno orijentiranom opozicijom, kao i smjene nacionalo i/ ili liberalno orijentiranih rukovodstava u drugim jugoslavenskim republikama tijekom 1972. imale su za cilj da osiguraju opstanak utjecaja frakcije koja je promicala samoupravne reforme i koja se sada našla u neugodnoj situaciji jer su njene reforme iz 60-ih dovele do bujanja neželjenih pokreta i ideja (nacionalizam, liberalizam), ali i osnažile pozicije "centralističkih" kritičara. Bakarićeva i Kardeljeva frakcija morala se represijom distancirati od neželjenih ideja i osoba i pokazati da samupravna reforma nije nužno povezana s tim zastranjenjima kao što su implicirali neki kritičari. ${ }^{33}$

31 Slavoljub Đukić, Slom srpskih liberala. Tehnologija političkih obračuna Josipa Broza, Beograd, 1990, str. 41-47.

32 Drago Tović, "'Jež' bez bodljikave maske", VUS, 10. III. 1971. (pretiskano u: Preporod hrvatskih sveučilištaraca, Zagreb, 1971, str. 209-210)

33 O zbivanjima u Hrvatskoj 1970-1971. i Bakarićevoj ulozi v.: Lampe, Yugoslavia as History, str. 305-311; Hrvoje Klasić, Hrvatsko proljeće u Sisku, Zagreb, 2006; Radelić, Hrvatska u Jugoslaviji, str. 434-451; Ramet, The Three Yugoslavias, str. 227-62; Goldstein, Hrvatska 1918-2008, str. 543-550; Mujadžević, Bakarić, str. 277-298; Tvrtko Jakovina (ur.), Hrvatsko proljeće 40 godina poslije, Zagreb, 2012. 


\section{Zaključak}

U razdoblju između 1966. i 1969. Vladimir Bakarić je kao čelna osoba SKH prenio težište svoga djelovanja na saveznu razinu. U vrhu SKJ promicao je nastavak samoupravne reforme koja prema njegovom shvaćanju nije bila dovršena. Savezne institucije i s njima povezani interesi još uvijek su prema njegovom mišljenju oduzimali preveliki dio prihoda od neposrednih proizvođača. Bakarić je u svojim istupima ponajviše predstavljao interese hrvatskih građana, za koje je smatrao da su posebno ugroženi jugoslavenskim bankarskim sustavom i prevelikim izdvajanjima za Fond za nerazvijene i velike infrastrukturne projekte. Također je neprestano ukazivao da je potrebno osnažiti tržišne elemente u jugoslavenskom gospodarstvu i suzbiti umjetnu i neekonomičnu privredu koja se oslanjala na državnu zaštitu. Kao glavnog oponenta interesima samoupravne reforme smatrao je idejno nekoherentnu skupinu koje je nazivao "centralistima", pristašama "starog sistema" ili "birokratizma", koja je pretežito djelovala u prijestolnici SFRJ i SR Srbije, Beogradu. Ova je skupina djelovala u saveznim i republičkim tijelima te u privredi i medijima. Bakarić je koristio svoj utjecaj u jugoslavenskom vrhu te u strukturama SRH da tijekom razdoblja 1966-1969. iza zatvorenih vrata i unutar partijskih foruma vodi kampanju protiv onoga što je nazivao "centralističkim" snagama, istovremeno preferirajući opreznu i balansiranu polemiku s njima preko medija pod njegovom kontrolom u SRH. Nakon Bakarićeva odlaska sa čela SKH 1969. novo hrvatsko rukovodstvo napustilo je njegovu opreznu politiku i upustilo se u žestoku javnu kampanju protiv stvarnog i izmišljenog "centralizma". 


\section{Summary}

Dino Mujadžević, Ph. D.

\section{Vladimir Bakarić's Stand on the „Centralist" Opposition (1966-1969)}

Key words: Vladimir Bakarić, stands, "centralists", Communist Party of Yugoslavia (KPJ), Aleksandar Ranković

Between 1966-1969, Vladimir Bakarić top party leader of SKH (League of Communist of Croatia) shifted the focus of his attention to the federal level. The reform of the self-management system passed unnoticed by the top leadership of SKJ (Communist League of Yugoslavia) but according to him it was not yet completed. In his opinion, the federal institutions and the vested interest of those connected with them were still taking away the larger part of the income earned by direct producers. It was Bakarić who mostly advocated the interests of Croatian citizens who he considered to be specially threatened by the Yugoslav banking system, excessive giving to the Fond for the Undeveloped and the large infrastructure projects. He also kept pointing out that it was necessary to strengthen the market elements in the Yugoslav economy and put an end to the artificial and ineffective economy that relied on state protection. He considered the main opponents of the self-management reform to be an ideologically non coherent group he called the "centralists" who supported the "Old system" or bureaucratism that was mostly active in the capital of the SFRY (Socialist Federal Republic of Yugoslavia) and Socialist Republic of Serbia - in Belgrade. This group was active in the federal and republic organs as well as in the economy and the media. Bakarić used his influence in the top Yugoslav leadership and in SKH structures from 1966-1969 to lead a campaign behind closed doors and inside the party forms against what he called "centralist" forces while at the 
same time preferred a cautious and balanced discussion with them in the media that was under his control in SRH (Socialist Republic of Croatia). After Bakarić left the top leadership position in SKH in 1969 the new leadership abandoned his cautious policy and engaged in a fierce public campaign against the real and imagined "centralism". 